\title{
Evaluating the Effectiveness of Designed Interventions on Improving Utilization of Antenatal Care (ANC) Contacts
}

\section{During Pregnancy}

\section{Abstract}

Antenatal care (ANC) is critical for the mother and child's health. WHO recommends 8 ANC contacts and Indian policy recommends at least 4 ANC contacts, with both pushing for the first contact to be within the first trimester. These requirements are not met in many districts in India due to a variety of reasons. Here, as a Phase I experiment, we plan to remotely test different types of framing of message interventions in order to improve attendance of 4 ANC contacts in two districts in Uttar Pradesh by measuring intentionality to avail ANC contacts and the value perception of ANC services.

\section{Introduction}

Antenatal care (ANC) is a critical window of opportunity to prevent adverse maternal and child health outcomes by tracking the well-being of mother and fetus and increasing preparedness for any anticipated complications ${ }^{1}$. Further, ANC is a critical platform to improve the likelihood of institutional delivery (ID). IDs can address primary maternal mortality factors such as sepsis and hemorrhage, responsible for $28 \%$ and $10 \%$ of all maternal death respectively, which are caused by delivery in unsanitary conditions and by unskilled birth attendants ${ }^{1}$.

WHO recommends 8 ANC contacts during pregnancy (See Table 1 for details). The Government of India recommends 8 ANC contacts with an emphasis on at least 4 contacts during pregnancy. While most women in rural and urban India attend at least one ANC visit (Table 2), the percent attending more than four is around 50\%. In two districts in Uttar Pradesh, which are the focus of this study, the percentage of women who attended at least 4 ANC check-ups are $9.6 \%$ and $22.3 \%$ respectively, according to NFHS4 $(44.1 \%$ and $24.9 \%$ according to validation data provided by IDinsight). 
Table 1. 2016 WHO ANC model

\begin{tabular}{|l|l|}
\hline First trimester Contact 1 & up to 12 weeks \\
\hline Second trimester Contact 2 & 20 weeks \\
\hline Contact 3 & 26 weeks \\
\hline Third trimester Contact 4 & 30 weeks \\
\hline Contact 5 & 34 weeks \\
\hline Contact 6 & 36 weeks \\
\hline Contact 7 & 38 weeks \\
\hline Contact 8 & 40 weeks \\
\hline Return for delivery at 41 weeks if not given birth. \\
\hline $\begin{array}{l}\text { Note: Intermittent preventive treatment of malaria in pregnancy should be started at } \geq 13 \\
\text { weeks. }\end{array}$ \\
\hline
\end{tabular}

Table 2: The timing and frequency information of ANC visits according to NFHS4 (2015-2016):

\begin{tabular}{|c|c|c|c|}
\hline \multicolumn{4}{|c|}{$\begin{array}{l}\text { Percent distribution of women age } 15-49 \text { who had a live birth in the five years } \\
\text { preceding the survey by number of antenatal care (ANC) visits for the most recent } \\
\text { live birth, and by the timing of the first visit, and among women with ANC, median } \\
\text { months pregnant at first visit, according to residence, India, 2015-16 }\end{array}$} \\
\hline $\begin{array}{l}\text { Number and timing } \\
\text { of ANC visits }\end{array}$ & Urban & Rural & Total \\
\hline \multicolumn{4}{|l|}{ Number of ANC visits } \\
\hline None & 9.3 & 19.6 & 16.5 \\
\hline 1 & 4.2 & 6.3 & 5.7 \\
\hline 2 & 8.5 & 14.0 & 12.4 \\
\hline 3 & 10.7 & 14.6 & 13.4 \\
\hline $4+$ & 66.4 & 44.8 & 51.2 \\
\hline Don't know/missing & 1.1 & 0.7 & 0.8 \\
\hline Total & 100.0 & 100.0 & 100.0 \\
\hline \multicolumn{4}{|l|}{$\begin{array}{l}\text { Number of months pregnant } \\
\text { at time of first ANC visit }\end{array}$} \\
\hline No antenatal care & 9.3 & 19.6 & 16.5 \\
\hline$<4$ & 69.1 & 54.2 & 58.6 \\
\hline 4-5 & 14.7 & 19.4 & 18.0 \\
\hline $6-7$ & 2.9 & 3.9 & 3.6 \\
\hline $8+$ & 3.9 & 2.8 & 3.1 \\
\hline Don't know/missing & 0.1 & 0.2 & 0.2 \\
\hline Total & 100.0 & 100.0 & 100.0 \\
\hline Number of women & 54,847 & 129,794 & 184,641 \\
\hline $\begin{array}{l}\text { Median months pregnant at } \\
\text { first visit (for those with ANC) }\end{array}$ & 3.3 & 3.6 & 3.5 \\
\hline Number of women with ANC & 49,771 & 104,404 & 154,175 \\
\hline
\end{tabular}


CSBC is working with NITI Aayog to support program efforts on antenatal care and institutional deliveries, by 1.) Conducting a system-level diagnosis to understand the barriers affecting delivery and uptake. 2.) Design and test behavior change interventions which can address these issues. 3.) Pilot and Scale-up successful solutions in collaboration with partners. Through primary and secondary research, as well as stakeholder interactions, we found high variability in the quality of ANC services provided. Challenges faced by frontline health workers in conveying the value of ANC contacts (other than material incentives) has led to women devaluing the ANC process. This coupled with rigid social norms around disclosure of pregnancies, has resulted in lowered motivation among women to participate in ANC contacts. Furthermore, women's participation in ANC is not adequately leveraged to provide counselling on institutional deliveries, which has led to many opting for unsafe, unsanitary home births.

Indicators of interest:

- Intention to utilize ANC visits

- Value perception of ANC visits

Based on our qualitative diagnosis, we designed interventions that we hypothesized would increase the value perception of ANC. Our main objectives for the interventions are:

1. Simplified communication, highlighting the unique identity of each of the 4 ANC visits in terms of benefits to the mother and child and risks associated with not availing timely care.

2. Increased awareness of this free and essential service emphasizing incentives provided, by framing them in non-pecuniary terms.

3. Detecting pregnancy signs and conveying the importance of registration of pregnancy with a health worker within the first trimester.

This document outlines a proposed experiment using randomized controlled methodology to assess the effectiveness of the proposed interventions in improving intention to utilize ANC contacts with the first contact completed within the first trimester; as well as other immediate outcomes including value perception of ANC, risk perception of not attending ANC, self-efficacy in relation to attending ANC contacts, and social norms surrounding ANC.

The experiment consists of testing different types of message framing of ANC interventions through a phone survey. Given the risks associated with the current COVID-19 pandemic, the experiment is planned for remote deployment and testing. This being a phase I concept testing experiment, we will use a pragmatic sample - women of reproductive age in our target demography instead of exclusively pregnant women. 


\section{Methods}

\section{Experimental Design Overview}

Our design is a framed field experiment. Women of reproductive age (18-45 yrs.) are eligible and randomly assigned to one of the 7 groups ( 6 treatment arms and one control). Details of the recruitment criteria and the treatment arms are explained in the following sections.

Recruitment is followed by one phone survey that includes both treatment deployment and a questionnaire to measure intentionality, value perception, knowledge, attitudes, past behavior, and standard demographics.

\section{Sample Identification}

Our sample consists of women registered in the Govindbhai C Patel Foundation from two districts in Uttar Pradesh - Fatehpur and Sonbhadra. Women within the ages of 18 to 45 years are contacted via IVRS (Interactive Voice Response System) asking for their consent to participate in this study. This foundation has a large and diverse database of phone numbers: 68099284 rural women, stratified by age (18-29, 30-44, 45-59, 60+), and income (low, mid, and high) within the state of UP. Along with the informed consent, they are also asked four screening questions which will be used for stratification during group assignment. Participants that consent will be assigned to one of 7 groups. The intervention and questionnaire are combined in a single phone survey. Details of the data collection are described below.

\section{Data Collection}

1. The women are sent an IVRS, i.e., a recorded message in Hindi asking for their consent to be given via a key press, and then asked four screening questions:
A. What is your age?
B. Are you currently pregnant? If yes, which month of pregnancy are you in?
C. Do you have children? If yes, how many?
D. What is the primary source of pregnancy related health care in your household?

2. Phone Survey

A. Informed consent is first confirmed along with the person's name, phone number and her answers to the four screening questions. While this is post group assignment and we can't alter the groups based on any corrections; during 
analysis we can ensure better control of these variables by making sure of their accuracy.

B. Each group then receives an audio message specific to that group (see Treatment Arms section below for details).

C. This is followed by questions on our primary outcome variables: intentionality to utilize ANC services and value perception of these ANC contacts.

D. Additional questions on attitudes, knowledge, beliefs and norms, and past behavior are included as secondary outcome variables. Demographic information is also collected, as they are useful covariates.

\section{Randomization}

Participants who give consent are to be assigned to one of 7 groups using stratified randomization. Stratified random sampling process ensures that equal numbers of pregnant and nonpregnant women are assigned to the different treatment arms. Similarly, assignment to treatment arms is controlled for age groups (18-25, 26-35, 36-45), number of children (no children, children) and primary source of medical care during pregnancy in their households (ANC, private care, home remedies).

\section{Treatment Arms}

We create a control group and 6 treatment groups characterized as: sanitation (control), gain frame, loss frame, 4 ANC visits renamed, testimonial, non-pecuniary frame, and registration within the $1^{\text {st }}$ trimester plus mental model of pregnancy detection.

Table 3 describes each of the treatment arms. The treatment deployment is done during the phone survey. An audio script is played by the enumerators, followed by questions to measure outcome variables. Duration of each message is also shown in Table 3. All the messages were recorded by the same female voice over artist. All messages are in Hindi, widely spoken in the two districts Fatehpur and Sonbhadra. They were written by the authors and translated by a professional copywriter. Scripts were tested on an appropriate sample to get feedback on the language, length, and their level of interest and engagement.

\section{Treatment Deployment}

Enumerators from the ZRC agency were hired to administer the phone survey on a licensed software, Survey CTO. Enumerators conduct the survey on the phone and type the answers into survey CTO (installed on a second device) simultaneously. The call itself is not recorded. The duration of the survey is around $\mathbf{3 0}$ mins. Only complete surveys will be used for analysis and 
no participants with partial surveys are recontacted to resume the survey. While the enumerators are familiar with the broad outline of the study, they are not made aware of the details of the treatment groups in order to reduce potential bias. However, as the enumerator can hear the intervention message played, they are not blind to the treatment arms while conducting the endline survey.

\section{Pilot data}

The entire questionnaire was tested on 14 participants, 2 per group. This pilot data was collected by the same enumerators, where the calls were recorded, to ensure the data quality and to address any concerns.

\section{Backcheck}

To ensure the quality of the data, $10 \%$ of the participants across treatment groups and enumerators will be chosen for an additional short survey. These surveys will be conducted a week after the main data collection by a separate set of enumerators. It will include a few questions about the previous survey length and comfort rating, the stated preference questions from before, a few knowledge, attitude, demographics and past behavior questions.

Table 3: A brief description of the message in each of the treatment arms.

\begin{tabular}{|l|l|l|}
\hline \multicolumn{1}{|c|}{ Treatment } & \multicolumn{1}{c|}{ Description of Message } & Duration \\
\hline T0: Control & $\begin{array}{l}\text { A description of ANC services followed by a } \\
\text { message on Swachh Bharat, public sanitation } \\
\text { project (unrelated to ANC) }\end{array}$ & 2 min 03 sec \\
\hline $\begin{array}{l}\text { T1: Gain Framing } \\
\text { message of ANC }\end{array}$ & $\begin{array}{l}\text { A description of ANC services followed by a } \\
\text { message describing the 4 ANC visits. } \\
\text { The tone is joyful. It highlights the unique } \\
\text { benefits and goals for each ANC visit. }\end{array}$ & 2 min $37 \mathrm{sec}$ \\
\hline $\begin{array}{l}\text { T2: Loss/Risk } \\
\text { Framing message of } \\
\text { ANC schedule }\end{array}$ & $\begin{array}{l}\text { A description of ANC services followed by a } \\
\text { message describing the 4 ANC visits. Closely }\end{array}$ & 2 min $28 \mathrm{sec}$ \\
\hline
\end{tabular}




\begin{tabular}{|c|c|c|}
\hline & $\begin{array}{l}\text { matched to the gain frame, it highlights the } \\
\text { risks of not attending ANC visits. }\end{array}$ & \\
\hline $\begin{array}{l}\text { T3: } \\
\text { Renaming/Rebrandi } \\
\text { ng the ANC visits }\end{array}$ & $\begin{array}{l}\text { A description of ANC services followed by a } \\
\text { message that assigns a unique identity to each } \\
\text { ANC visit, giving it a name and a tagline. }\end{array}$ & $1 \mathrm{~min} 38 \mathrm{sec}$ \\
\hline $\begin{array}{l}\text { T4: Joyful } \\
\text { Testimonial of the } \\
\text { ANC visits }\end{array}$ & $\begin{array}{l}\text { A description of ANC services followed by a } \\
\text { message with a joyful testimonial describing } \\
\text { the ANC visits and its benefits. }\end{array}$ & $2 \mathrm{~min} 32 \mathrm{sec}$ \\
\hline $\begin{array}{l}\text { T5: Non-Pecuniary } \\
\text { Framing of the } \\
\text { monetary incentive }\end{array}$ & $\begin{array}{l}\text { A description of ANC services followed by a } \\
\text { message describing the monetary incentives } \\
\text { for completing ANC visits. It is framed as a } \\
\text { conversation between two women, } \\
\text { highlighting non-pecuniary possibilities of the } \\
\text { incentives provided. }\end{array}$ & $2 \mathrm{~min} 04 \mathrm{sec}$ \\
\hline $\begin{array}{l}\text { T6: Message for } \\
\text { registration within } \\
1^{\text {st }} \text { trimester }\end{array}$ & $\begin{array}{l}\text { A description of ANC services followed by a } \\
\text { message describing the heuristics for detecting } \\
\text { pregnancy with a call for registration within the } \\
1^{\text {st }} \text { trimester. }\end{array}$ & $1 \mathrm{~min} 59 \mathrm{sec}$ \\
\hline
\end{tabular}

\section{Sample Size Determination}

Our sample size is based on similar previous studies. This being a phase I study, we leaned towards a smaller sample to get a quick estimate of how our various messages compare. Datta et al., $2014^{2}$ showed some efficacy of text-based messaging in improvement of ANC visits in rural Tamil Nadu using 120 people. They saw an increase in their knowledge score of ANC visits with an effect of 0.34 (Cohen's h). With 100 as an estimate and 7 groups, we need a sample of 700 women. Allowing for a buffer of $25 \%$ of data to account for exclusion due to not participating in the survey (after providing consent via IVRS) and incomplete surveys, we need 934 women to consent to participate. With a $3 \%$ recruitment rate (seen in previous such studies) via mass IVRS, we need to contact 31,134 people. With a sample of 100 per group, a 
$95 \%$ confidence interval, and power of 0.8 , we can expect to detect a group difference with an effect size of 0.4 (Cohen's d) or above.

\section{Outcome Variables}

Our participants are women of reproductive age instead of exclusively pregnant women. Thus, we cannot measure actual behavior of registration within the $1^{\text {st }}$ trimester or adherence to ANC schedule. We primarily want to test the different types of framing of messages on a smaller sample. The treatment is a short message deployed only once, immediately before the survey. This limits the expected effect size of change in any outcome variable between treatment and control groups. However, it allows us to gain insight on the efficacy of our different messages through trends and help narrow down the intervention choices for Phase II with a larger sample.

Theory of $\mathrm{KAP}^{3}$ (knowledge, attitude and practice) and $\mathrm{TPB}^{4}$ (theory of planned behavior) predict the role of knowledge, attitudes (such as risk perception and value perception), social norms, self-efficacy or perceived behavioral control, and demographics, in determining behavior. It also proposes intentionality to be the most immediate and important predictor of behavior $^{\prime 4}$. Our primary outcome variables are intentionality to avail adhere to the ANC schedule and value perception of the ANC services. See Table 4 for a description of primary outcome variables. Our questionnaire also includes questions on knowledge of ANC schedule, risk perception of not attending all 4 ANC visits or failing to register pregnancy within the first trimester, social norms behind adhering to the ANC schedule and registering the pregnancy within the first trimester, confidence in one's ability to attend all 4 ANC visits at the prescribed times, and demographics such as household income and caste. We hypothesize that the increase in intention to adhere to the ANC schedule and the value perception of the ANC services is caused by increase in risk perception of non-compliance, knowledge of the ANC services, increased perception of adherence to ANC schedule as a social norm etc. See Table 5 for a full list of secondary outcome variables below and how the outcome measure is created for each construct. 
Table 4: Description of primary variables

\begin{tabular}{|c|c|c|}
\hline $\begin{array}{l}\text { Outcome } \\
\text { Variable }\end{array}$ & Description ${ }^{1}$ & Outcome Measure \\
\hline $\begin{array}{l}\text { Stated } \\
\text { Preference: } \\
\text { Intentionality }\end{array}$ & $\begin{array}{l}\text { likelihood ratings from } 1-5 \text { : } \\
\text { - registration within } 1^{\text {st }} \text { trimester } \\
\text { - attending at least } 1 \text { ANC }\end{array}$ & $\begin{array}{l}\text { Raw likert score. Measured on a Likert } \\
\text { Scale (1-5). } \\
\text { Variable type: Two Ordinal variables } \\
(1-5) .\end{array}$ \\
\hline \multirow[t]{2}{*}{$\begin{array}{l}\text { Revealed } \\
\text { Preference: } \\
\text { Value } \\
\text { Perception }\end{array}$} & $\begin{array}{l}\text { 1.) Are they willing to donate INR } 20 \\
\text { out of INR } 50 \text { endowment to get } \\
\text { more information either on ANC } \\
\text { services or the monetary incentives } \\
\text { provided on completion of ANC } \\
\text { visits? }\end{array}$ & $\begin{array}{l}\text { Variable type: Two dummy variables } \\
\text { Donate INR } 20 \text { for ANC services } \\
\text { Information = 1, else } 0 \\
\text { Donate INR } 20 \text { for ANC Monetary } \\
\text { Incentives Information = 2, else } 0\end{array}$ \\
\hline & $\begin{array}{l}\text { 2.) How much are they willing to pay } \\
\text { per ANC visit? Price is estimated by } \\
\text { a titration procedure. }\end{array}$ & $\begin{array}{l}7 \text { Steps (INR 20, 40, 60, 80, 100, 120, } \\
\text { 140) } \\
\text { An additional step for people who } \\
\text { refuse to pay INR } 20 \text { (the minimum } \\
\text { step). } \\
\text { Variable type: Numerical (1-8) }\end{array}$ \\
\hline
\end{tabular}

\footnotetext{
${ }^{1}$ For further details on all outcome measures across tables, please refer to the survey instrument here.
} 
Table 5: Description of secondary variables

\begin{tabular}{|c|c|c|}
\hline $\begin{array}{l}\text { Outcome } \\
\text { Variable }\end{array}$ & Description & Outcome Measure \\
\hline Knowledge & $\begin{array}{l}\text { A total of } 7 \text { questions on ANC } \\
\text { schedule, registration and monetary } \\
\text { benefits. }\end{array}$ & $\begin{array}{l}\text { Number of correct responses } \\
\text { across } 7 \text { questions. } \\
\text { Variable type: Numerical }(0-7)\end{array}$ \\
\hline Risk perception & $\begin{array}{l}2 \text { Likert scale ratings of perceived } \\
\text { harm due to late registration and } \\
\text { non-compliance with ANC schedule. } \\
\text { Same scale for both, with } 1 \text { being no } \\
\text { harm and } 5 \text { most harm. } \\
2 \text { yes/no questions on } \\
\text { acknowledging risk associated with } \\
\text { late registration and non-compliance } \\
\text { with ANC schedule. }\end{array}$ & $\begin{array}{l}\text { Number with Likert-scale } \\
\text { response ' } 2 \text { ' and above for the } \\
\text { scale questions } \\
\text { added to } \\
\text { Number of questions with } \\
\text { response 'yes' for the binary } \\
\text { questions. } \\
\text { Variable Type: Numerical }(0,1,2 \text {, } \\
3,4)\end{array}$ \\
\hline $\begin{array}{l}\text { Perceived } \\
\text { norm }{ }^{2}\end{array}$ & $\begin{array}{l}3 \text { questions using Likert scale rating } \\
\text { of likelihood (1-5) of what most } \\
\text { women would do: } \\
\text { - register within first trimester } \\
\text { - consider } 4^{\text {th }} \text { ANC visit most } \\
\text { important } \\
\text { - consider 1-2 ANC visits enough }\end{array}$ & $\begin{array}{l}\text { Number with Likert-scale } \\
\text { response ' } 3 \text { ' and above for the } \\
\text { scale questions } \\
\text { Variable Type: Numerical }(0,1,2 \text {, } \\
\text { 3) }\end{array}$ \\
\hline
\end{tabular}

\footnotetext{
${ }^{2}$ Note: two other questions on reasons for late registration and non-compliance will be treated as qualitative data and not part of this analysis.
} 


\begin{tabular}{|c|c|c|}
\hline Self-efficacy & $\begin{array}{l}2 \text { questions using Likert scale ratings } \\
\text { of confidence (1-5) in own ability to } \\
\text { - register own pregnancy within 1st } \\
\text { trimester } \\
\text { - attend all } 4 \text { ANC visits if pregnant }\end{array}$ & $\begin{array}{l}\text { Number with Likert-scale } \\
\text { response ' } 3 \text { ' and above for the } \\
\text { scale questions } \\
\text { Variable Type: Numerical }(0,1,2)\end{array}$ \\
\hline Trust-efficacy & $\begin{array}{l}2 \text { trust ratings ( } 1-5,1 \text { being highly } \\
\text { distrust and } 5 \text { being highly trust) on } \\
\text { - Govt provided services } \\
\text { - whether this survey faithfully } \\
\text { represents information given by the } \\
\text { govt. }\end{array}$ & $\begin{array}{l}\text { Number with Likert-scale } \\
\text { response ' } 3 \text { ' and above for the } \\
\text { scale questions } \\
\text { Variable Type: Numerical }(0,1,2)\end{array}$ \\
\hline Past behavior ${ }^{3}$ & $\begin{array}{l}\text { On a subset of previously pregnant } \\
\text { women: } \\
\text { Registered pregnancy: never, after } \\
1^{\text {st }} \text { trimester, within } 1^{\text {st }} \text { trimester } \\
\text { No. of ANC visits: } 0-8+\end{array}$ & $\begin{array}{l}\text { Registered pregnancy categorical } \\
\text { variable }(0,1,2) \text { and ANC visit } \\
\text { number discrete variable added } \\
\text { together. }\end{array}$ \\
\hline
\end{tabular}

Demographic information is also collected, which will be used as covariates. See Table 6 for a full description of these variables.

\footnotetext{
${ }^{3}$ Note: 2 other questions on reasons for late registration and non-compliance, treated as qualitative. 2 more on pregnancy information source and pregnancy care source are already represented by the 'pregnancy care source' stratification, hence not included.
} 
Table 6: Description of demographic variables:

\begin{tabular}{|c|c|c|}
\hline $\begin{array}{l}\text { Outcome } \\
\text { Variable }\end{array}$ & Description & Outcome Measure \\
\hline \multirow[t]{6}{*}{$\begin{array}{l}\text { Covariates: } \\
\text { Demo- } \\
\text { graphics }\end{array}$} & $\begin{array}{l}\text { Marital status: } \\
\text { Unmarried, married, } \\
\text { divorced/separate, widowed }\end{array}$ & $\begin{array}{l}2 \text { levels: } 1=\text { married, } 2=\text { other } \\
\text { Binary variable }\end{array}$ \\
\hline & $\begin{array}{l}\text { Completed education level: did not go } \\
\text { to school/ did not complete primary } \\
\text { school, primary school, secondary } \\
\text { school, undergraduate degree, post- } \\
\text { graduate degree, }\end{array}$ & $\begin{array}{l}\text { Raw data used. } 5 \text { levels: } \\
1,2,3,4,5 \\
\text { Variable Type: Ordinal (1-5) }\end{array}$ \\
\hline & People in the household. & $\begin{array}{l}\text { Grouped into } 3 \text { or less, 4-7, 8+ } \\
\text { Variable Type: Ordinal (1-3) }\end{array}$ \\
\hline & Monthly Household Income & $\begin{array}{l}\text { Logarithm of household income } \\
\text { per person } \\
\text { Variable Type: Continuous }\end{array}$ \\
\hline & $\begin{array}{l}\text { Religion and Caste combined: Hindu- } \\
\text { General, Hindu-OBC, Hindu-SC, Hindu- } \\
\text { ST, Muslim, Christian, Sikh, Buddhist, } \\
\text { Other }\end{array}$ & $\begin{array}{l}\text { Variable (1-9) } \\
\text { Variable Type: Categorical (1-9) }\end{array}$ \\
\hline & $\begin{array}{l}\text { Time to travel to the health center: less } \\
\text { than } 5 \mathrm{~min}, 5-10 \mathrm{~min}, 10+\end{array}$ & $\begin{array}{l}\text { Variable }(1,2,3) \\
\text { Variable Type: Ordinal (1-3) }\end{array}$ \\
\hline
\end{tabular}




\begin{tabular}{|l|l|l|} 
& $\begin{array}{l}\text { Employment Status: Employed, } \\
\text { unemployed, homemaker }\end{array}$ & $\begin{array}{l}\text { 2 levels: } 1=\text { Employed, } 2=\text { other } \\
\text { Binary variable }\end{array}$ \\
\hline
\end{tabular}

\section{Model Specifications}

Ordered Logistic Regression will be used for ordinal outcomes (2 stated preference measures), logit regression for categorical variable ( $1^{\text {st }}$ revealed preference measure), and Ordinary Least Squares for the numerical variable ( $2^{\text {nd }}$ revealed preference measure).

Ordinary Least Squares will be used for discrete numerical variables ( 5 secondary outcome measures estimated by all the questions within each construct, except the knowledge construct).

For the knowledge variable, we will apply censoring, using a Tobit regression model.

Note: The past behavior secondary outcome variable analysis will depend on the sample we recruit. If numbers of previously pregnant women are insufficient within each group, then this variable will not be analyzed.

For every outcome measure we will use two models, with and without controlling for demographic information. This is repeated for each of the 6 treatment groups.

With 4 primary outcome measures, 6 treatments and 2 models, this makes 48 hypothesis tests. Thus, we use multiple hypothesis testing adjustments with pFDR and the q-value ${ }^{5}$.

$\mathrm{M} 1: \mathrm{Y} \sim$ treatment_assignment + strata_age + strata_pregnancy_status + strata_number_children + strata_primary_source_pregancy_care + error $\mathrm{M} 2: \mathrm{Y} \sim$ treatment_assignment + strata_age + strata_pregnancy_status + strata_number_children + strata_primary_source_pregancy_care + demographic_covariates + error

$\mathrm{Y}=$ outcome measures in Table 4 (4 primary outcome measures), and in Table 5 ( 6 secondary outcome measures)

treatment_assignment $=$ dummy variable, 1 for treatment and 0 for control.

strata_age $=$ stratified by 3 age groups $(18-25,26-35,36-45)$ 
strata_preganacy_status $=1$ for pregnant, 2 for not pregnant

strata_number_children $=1$ for children, 2 for no children

strata_primary_source_pregancy_care $=$ stratified by primary source of pregnancy care in the household, 1 = ANC, 2 = private care, 3 = home remedies.

All analysis including randomization, data checks, etc. will be conducted using custom-made MATLAB (The MathWorks, Inc) scripts in R (R Core Team, 2014) ${ }^{6}$. 


\section{Bibliography}

1. L Say, D Chou, A Gemmill, Tunçalp O, Moller A-M, Daniels J, Gülmezoglu AM, Temmerman M, and Alkema L. (2014). Global Cause of Maternal Death: a WHO systematic analysis. The Lancet Global Health, 2(6), e323-e333. http://dx.doi.org/10.1016/S2214-109X(14)70227-X

2. Datta SS, Ranganathan P, and Sivakumar KS. (2014). A study to assess the feasibility of Text Messaging Service in delivering maternal and child healthcare messages in a rural area of Tamil Nadu, India. AMJ, 7(4), 175-180. http://dx.doi.org/10.4066/AMJ.2014.1916

3. Webb TL, Sheeran P. (2006). Does Changing Behavioral Intentions Engender Behavior Change? A Meta-Analysis of the Experimental Evidence. Psychological Bulletin, Vol. 132, No. 2, 249-268.

4. Kim TR, Ross JA, Smith DP. (1969). Trends in Four National KAP Surveys, 1964-67. Studies in Family Planning, Jun., 1969, Vol. 1, No. 43 (Jun., 1969), pp. 6-11

5. Storey, JD. (2002). A direct approach to false discovery rates. Journal of the Royal Statistical Society: Series B (Statistical Methodology). 64 (3): 479-498. https://doi.org/10.1111\%2F1467$\underline{9868.00346 .}$

6. R Core Team (2014). R: A language and environment for statistical computing. R Foundation for Statistical Computing, Vienna, Austria. URL http://www.R-project.org/ 